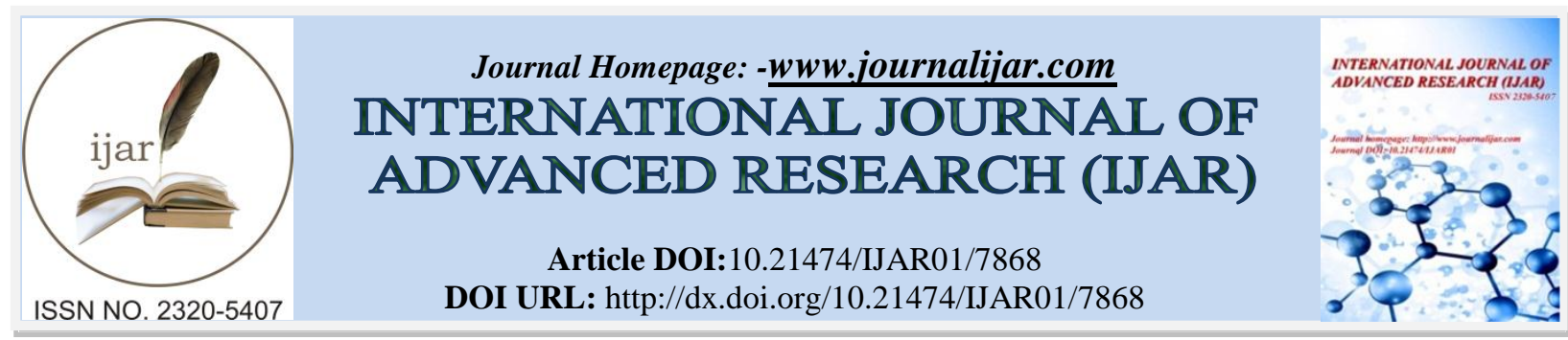

RESEARCH ARTICLE

\title{
AGRARIAN DISCONTENT AND THE PEASANTS RESISTANT MOVEMENT OF FRONTIER BENGAL : AN OVERVIEW.
}

Dr. Nirmal Chandra Mudi.

Assistant Prof.Department of History Bankura Sammilani College.

\section{Manuscript Info}

\section{Manuscript History}

Received: 9 August 2018

Final Accepted: 11 September 2018

Published: October 2018

Keywords:-

Jungal Mahals,peasants resistance movement ,Historiography, Subaltern perspective.

\section{Abstract}

A series of Tribal revolt was organized in jungal Mahals and Manbhum (hilly area of south west Bengal)during the colonial period.In 1799 an important tribal revolt was started in jungal mahals led by the jangal zamindar.This rebellion mostly familiar as 'Chuar Rebellion'.Durjan Singh was the leader of this revolt,zaminder of Raipur parganas.On ther other hand in1832 a another tribal revolt was revealed in frontier Bengal due to the British revenue policy led by the Ganganarayan Sing Zaminder of Barabhum Parganas.In 1857 an important agrarian discontent was organized against the British by the tribal chiefs of Panchokote raj Zamindars.These revolts are the symbol Indian freedom Movement. Jungal Mahals literally ,Jangal Estate', was a district formed by the British Government in 1805 for the interest of the British colonial power.After Ganganarayan Hungama in the Barabhum Estae the British Government realized the serious situation of jungal Mahals and for controlling the rebellious condition of that area. rebellion The Junglmahas district basically familiar as hilly area.Presently,modern Bankua,Purulia and Midnapore district is situated in this region.Jungal mahal the the adjoining part of Chhotanagpur plateau and mostly populated by the tribes.Not only the tribes but also some other nontribal communities resided in this region from the very beginning. Some tribal Zamindari chiefs was the ruler of this "Bhum suffix" area.During the zamindari era not a single revolt was organized by the tribes against the zamindars.Because a healthy socio-economic atmosphere were there.It was zamindari chiefs who appreciated for the development of the tribes both the socio and economics condition. The British East India Company,After receiving the Great Dewani of 1765 tried to establish their power in this region,and tried to establish a new revenue system on the peoples of that area that was extreeme and was unbearable. As a result all the peoples they rose their voice against the British revenue policy led by the Zaminadrs.It's have a glorious past history of anti-British struggles for independence.It is fact that,from the last half of the eightieth century a series of Anti-British rebellion was revealed by the rebellious peoples of the jungal Mahals. They truly understood the independence.Different historian they did not pay much attention to the rebellions in proper ways.In their writings we have seen some limitation that was not a historic analysis. Through this article we will try to reevaluate thse Tribal resistant movement. 


\section{Introduction:-}

History is a very interesting subject. The study of any historical occurrence is filled with debates and contradictions. It is viewed from various different perspectives and makes a wide variety of opposing assumptions. It is even more fascinating in India's case; the study of anti-colonial movement in India has been done from four major different perspectives: Imperialist Approach, Marxist Approach, Nationalist Approach and Subaltern Approach. The subaltern studies introduced a new trend in the historical research in modern Indian historiography. The subaltern scholars, led by Ranajit Guha, were dissatisfied with the interpretations of India's anti-colonial movement because this historiography had been dominated by an elitism of colonialists, bourgeois nationalists, and even orthodox Marxists, who had signally failed to take into account the contributions made by the people on their own, that is, independently of the elite. According to Guha, elitist historiography (The belief that certain persons or members of certain classes or groups deserve favored treatment by virtue of their perceived superiority, as in intellect, social status, or financial resources thus leading to the control, rule, or domination by such a group or class) ignored the "politics of the people", or the subaltern classes, in the making of the Indian nation. For Guha, the vast historiography of the Freedom Movement was "un-historical", "blinkered", and "one-sided" because it primarily focused on the domain of elite politics while silencing and refusing to interpret subaltern pasts.

\section{Modern Historiography:}

Indian freedom movements of South -West Bengal have a glorious past of freedom movement in India against the British colonial power. Subaltern peoples of this region raised their voice against exploitative politics of the colonial rules and strong arm tactics of the unscrupulous elements like Zamindars, moneylenders, and so on, which not only tended to destroy their means of livelihood but also put unbearable financial burden on them. I think the regional history in general and the anti-colonial movements of South-West Bengal in particular have not been highlighted properly in elitist historiography. In this article, I am trying to highlight the contribution made by subaltern group in various kinds of revolts occurred during the period from 1799 to 1857 in South -West Bengal. I believe that some important ideas will be disclosed through this paper.

From the Latin roots sub- "below", and alternus -"all others", subaltern is used to describe someone of a low rank (as in the military) or class (as in a caste system). Subalterns occupy entry-level jobs or occupy a lower rung of the "corporate ladder." But the term is also used to describe someone who has no political or economic power, such as a poor person living under a dictatorship. Different kinds of synonyms are used for the word 'Subaltern', like: common people, lower-class, underprivileged, exploited, inferiors, minors, weak etc. British Historian, E.P. Thomson wrote an article in 'The Times Magazine', while giving his opinion he used the words 'History from Down Below" In describing "history told from below", 'subaltern' was coined by Italian Marxist thinker Antonio Gramsci, notably through his work on cultural hegemony, which identified the groups that are excluded from a society's established institutions and thus denied the means by which people have a voice in their society Antonio Gramsci has used the word 'subaltern' for minor, poor, downtrodden people. Subaltern means overlooked, neglected, disregarded, and treated with unconcern and indifference'. Gramsci began using the term 'subaltern' to signify those made subordinate by hegemonies of power (of state, class, patriarchy, gender, race, and so on). Gramsci's concern with the state and culture is important in understanding how the term subaltern can indicate a person or community in a position "inferior" to others in some fundamental way (i.e., by class, caste, gender, location, and so on). However, it also can be used as a term to designate the relationship of two entities to each other vis-a-vis their access to power or capital (of the material and social varieties). Therefore, one might speak of a "subaltern" person but also of subalternity as a condition of being for everything from a community to a nation to a particular discourse (a set of texts, of practices, of histories, and so on). In critical theory and post colonialism, the term 'subaltern' designates the populations which are socially, politically and geographically outside of the hegemonic power structure of the colony and of the colonial homeland. That means the lower classes and the social groups who are at the margins of a society.

The word 'subaltern' as given in the Oxford Dictionary stands for the general attribute of subordination, which is expressed in terms of a caste, class, gender, office or any other way. It includes the characteristics of defiance and submission. Thus, in literal sense, it conveys 'view from below', i.e., a view or understanding from the bottom of society or the flow of knowledge from below. 
The term subaltern signifies tribal (Adivasis), low caste agricultural laborers, sharecroppers, smallholder peasants, artisans, shepherds, and migrant landless labour working in plantations and mines. The term is also not just a substitute for peasantry or laboring poor/common people - it alludes to recognition of the dialectical relationships of super-ordination and subordination that define social relations in hierarchical social formations. That means, a subaltern is someone with a low ranking in a social, political, or other hierarchy. It can also mean someone who has been marginalized or oppressed.

Subaltern theory takes the perspective of the "Other" as the one who has had no voice because of race, class, or gender. Subaltern Studies began its impressive career in England at the end of the 1970s, when conversations on subaltern themes among a small group of English and Indian historians led to a proposal to launch a new journal in India. Oxford University Press in New Delhi agreed instead to publish three volumes of essays called "Subaltern Studies: Writings on South Asian History and Society". These appeared annually from 1982 and their success stimulated three more volumes in the next five years, all edited by Ranajit Guha. When he retired as editor in 1989, Ranajit Guha and eight collaborators had written thirty-four of forty-seven essays in six Subaltern Studies volumes, as well as fifteen related books. Readings of Subaltern Studies began in India, where writing about Subaltern Studies began in book reviews. At first, each volume in the series was reviewed separately as collection of essays, but by 1986, an accumulation of writing inside and outside the project had established a distinctive school of research whose adherents came to be called "subalternists" or simply, "subalterns." Their seminal essays appeared in paperback in 1988, when Selected Subaltern Studies was published by Oxford University Press in New York and Oxford, edited by Ranajit Guha and Gayatri Chakravorty Spivak, with a foreword by Edward Said. By 1990, Burton Stein could cite the growing interest in Subaltern Studies as one sign that the 1980s were "a decade of historical efflorescence" in South Asian studies. In the 1990s, Subaltern Studies became a hot topic in academic circles on several continents; a weapon, magnet, target, lightning rod, hitching post, icon, gold mine, and fortress for scholars ranging across disciplines from history to political science, anthropology, sociology, literary criticism, and cultural studies. The original substance of Subaltern Studies emerged from work-in-progress in the late seventies. Eleven authors in the first three volumes -- Shahid Amin, David Arnold, Gautam Bhadra, Dipesh Chakrabarty, N. K. Chandra, Partha Chatterjee, Arvind N. Das, David Hardiman, Stephen Henningham, Gyanendra Pandey, and Sumit Sarkar -- were doing close empirical work in social, economic, and political history.

\section{Subaltern focused:}

It is an important approach to the study of tribal peasant movement. This perspective seeks to restore a balance by highlighting the role of the 'masses' as against the elite politics. The whole trust of subaltern historiography is on reconstructing the other history, i.e., the history of people's politics and movement and their attempts to make their own history. This perspective emphasizes not to view peasant or tribal insurgents merely as 'object' of history but to treat them as makers of their own history.

These subalternists focused their attentions on the circle of elite politics and have emphasized the insurrectionary activities and potential of the 'subaltern' classes (poor peasants, landless laborers, tribals etc.) to make these classes possessed self-conscious and coherent conception of resistance that was directed against rich peasants, urban traders or the colonial administrator.

The general concern about subalterns implied a commitment to the notion of social justice for oppressed and subordinated people. The subaltern historiography helps us understand people's lives, their actions, and their histories more meaningfully in terms of developing strategies for future action. In order to develop strategies, the Subaltern Studies develop a historiography which helps to create an emancipator politics for the subalterns or the lower and subordinated classes.

An important approach to the study of tribal/peasant movements has been enunciated by Ranajit Guha and his historian colleague in India and abroad.Broadly designated as 'Subaltern historiography', this approach seeks to resotre a balance by high lighting the role of the politics played in Indian History. ${ }^{1}$ Thus, 'elite'and 'people'are viewed as binary domains to constitute a structural dichotomy. Adherence to this approach argue that the elitist historiography, whether of the neo-colonialist or of the neo-nationalist variety ,has always over stated the part the elite has played in building Indian Nationalism , but it has failed to acknowledge ,far less properly interpret ,the 
contributions made by the people(masses)on their own ,independently of the elite. ${ }^{2}$ Parallel to the domain of elite politics there always existed throughout the colonial period another domain of Indian Politics in which the principal actors were not the dominant groups of the indigenous society but the 'subaltern'classes and groups constituting of masses of the laboring population and the intermediate strata in the town and the country---of the people. ${ }^{3}$ we are not going to the subaltern concept in details but trying to give focus on the regional history with special reference to the history of jungle Mahal .From the early stages of the British government they tried to established the new economic policy for the interest of the colonial power in the above mentioned area.But the peoples of the Jungle Mahal rose their voice against the British Revenue policy.Not only the tribals all the masses of jungle Mahal took part directly or indirectly against the British.Therefore,we can not categories all the Rebelled of jungle Mahal as "Peasant resistance movement".

Are the peasant and tribal insurgencies in colonial India 'pre-political'or 'political phenomena " ?Ranajit Guha the subaltern historian remember that 'pre-political' is as misleading as it value-laden., it helps us the least in understanding the experience of such movements in colonial India.Tribal or peasant insurgencies have to be understood in the backdrop of the attempts of the colonial state to revitalize landlordism and to promote parasitic landlordism.The peasant and tribal tenant rebelled against Sarkari,Sahukari,and zamindari oppression to which they were subjected.The uprising of Bhumij,the Kol insurrection ,the Santal revolt of 1885, the indigo disturbances of 1859-62, and the Deccan riots of 1875 in the nineteenth century come to mind almost immediate.The subaltern insurgents were then trying to break and destroy the then existing structure of power relationships. ${ }^{4}$

\section{Various movment:}

Attempts have been made by the historians to explain the "Chuar" and "Paiks revolts" as rebellions of the Paiks directed against "the maladministration of the British officials and native suboridinates., They rose a body against the British. They had suffered the most on account of the short -sighted policy of government . since in the south west Bengal Presidency series of peasant resistance movement took place. There were revolts of the jungle Zamindars in 1765-73,Chuar Revolt.of 1798-99,Khurda Revolt of 1817,"Ganganarayan Hangama” and the Kol rebellion of 1833,Santhal rebellion of 1856 and the revolt of Surendra Sai of Sambalmpur throughout the middle of the nineteenth Century. ${ }^{5}$ All these Resistance movements were undertaken by the old Zamindari militia of the paiks because the British revenue experiments led to resumption of their paikan lands resulting in their loss of prestige and financial privilege in the agrarian society. The revolt were, no doubt, movement,popular as the general population lent support to these movements.It whould be tempting to aggregate these movements with the Sepoy Mutiny of 1856-57 or to analyse the nature of these revolts as the first spark of national liberation movement of India.Like the Sepoy rebels the Khurda paiks urged the reluctant Khurda Raja to lend his support to the movement.Like Surendra Sai of Sambalpur its leader Jagabandhu Bidyadhar, who in 1803 supported the British annexation of Orissa to legalise his landed possessions forcibly occupied during the Maratha regime,only turned national leader of the rebels when his possessions were sold out collusively by the Bengali speculator.In the Jungle Mahals also the Dhalbhum Zamindar Jagannath Dhal or Rani Shiromoni of Karnogargh turned to be national leaders of the rebel Paiks who were dispossessed of their non-revenue paying Paikan lands and turned destitute paupers. ${ }^{6}$

\section{British Revenue Policy:}

The British revenue experiments resulting in the farming system and the permanent settlement provoked not only popular discontent but also sharp criticism from the British philanthropists. As an instance, Alexander Dow and Henry Pattulo criticized the agrarian policy of the Company's Government and traced the decline of Bengal from the beginning of the British rule which was equated with the Roman rule of Europe. Opponents of Warren Hestings like Philip Francis, advocates of "laissez fair economics" like Adam Smith and liberal Historians like James Stuart Mill vehemently criticized the revenue experiments of the Company as tyranny and 'misgovernment'. But these philanthropists did not want termination of British colonialism in the Bengal Presidency. It had been pointed out by

1. D.N.Dhanagare,., Themes and perspective in Indian Society,P.131

2. Ibid.

3. Ibid.

4. Ranajit Guha (ed) Subaltern Studies, Vol-II, P.8.

5. Dr.B.S.Das, Changing profile of South West Bengaal, P.155

6. Ibid. 
the Marxist writers that they wanted to put an end to colonialism based on merchant capital and to inaugurated a "industrial capitalism". To them short term farming settlements were the manifestation of marchant capitalism in Great Britain which brought termination of the trade monopoly of East India Company in India in 1833.Karl Marx pointed out that the permanent settlement in the Bengal Presidency was no solution to colonial exploitation but the aim of the industrial capital was to convert feudal India into an economic appendage of the industrial England.Marx noted that under the new arrangement there occurred 'the confiscation of ryot lands in favour of the zamindar., who acquired absolute power to place the ryots.Under the permanent settlement ,Marx observed , "the condition of the ryots were humbled and oppressed still more and the whole revenue system was thrown out of great causing whole series of local risings of ryots against the Landlords. ${ }^{7}$ Following Marx the Indian Marxist historians analysed the peasant the revolts in Rangpur (1783) and Pabna (1873) as the resistance movements of the peasants against the new landlords who "belonged to a section nouveaux richers".grown rich by taking advantage of trends which were accelerated by the early British occupation of Bengal. ${ }^{8}$ To them in the period of dominance of industrial capitalism , the peasant was invariably the worst victim of the colonial oppressions. The resistance of the of the peasants, however,took varied forms ranging from mass desertion,pertaking of the character of passive resistance and rising upto violent revolts. ${ }^{9}$ Analysing in this light,it would appear that the paik and chuar revolts were the peasant resistance movements against new landlordism. This was the certain of the rule of Great Britain dictated by the industrial capitalism which spread its wings all the world over.Thus the Paik rebellion was the part of the long series of revolts which took place all the world over against British capitalism. ${ }^{10}$

\section{Historian observations:}

Since the later half of the eighteen century beginning with W.W.Hunter and J.C.Price many treatises have been written on the Chuar Rebellion.The British historians analysed the revolt as a law and order problem of a region where the Zamindars,unmindful to respect law (as interpreted by Pax Britanika)followed a policy of mutual annihilation on the face of enhanced reveue demands of the Mughal emperors and later on of the Company's government with the help of their paik militia who belonged to the class of Chuar and enjoying the fruits of nonrevenue paying lands on lease hold tenure which were actually cultivated by the migrant pahi rayats with their own implements. It was accepted that "Pahi Rayats" of the paikan lands were also the Thani Rayats of the rent settled land of the zamindari in earnest need of counterbalancing loss from enhanced money rent of reconstructed rent-roll. The British historians justified their military engagements for restoring rule of law in the jungle Mahal which could only ensure a period of stability for enhancing and a perfect competitive marked condition necessary in return would for enhancing yielding capacity of the soil which in returned would benefit the settled rayats with the elimination of the unproductive social parasitism by abolishing non-resumed non-revenue paying tenures. ${ }^{11}$ They shut their eyes to understand the fact that the tribal peasant economy on the pillar of an imperfect money market was a way of life,a pursuit for survival against hostile nature not dictated by profit motive in a pre-captitalist social formation of the frontier Bengal. ${ }^{12}$ The nationalist historians of the twentieth century,eulogized these resistance movements as tribal revolts to regain political independence lost during the Mughal period.These revolts are the culmination of unrest against the "Hinduization" policy of the caste Hindu rulers and merchants which broke down their tribal exclusiveness exposing them to the challenges and exploitations of the capitalist market forces developing all over the world under the umbrella of the Pax-Britanika.They have cared "to distinguish between the

7. Marx:Notes in Indian history, 116-120

8.Kalyan Kr.Das Gupta:The agrarian league of Pabna,1873,IESHR,Vol,7,No.2,P-225,Radharaman Mukherjee,occupancy Ryots,Calcutta,1919,P.74.,

N.K.Sinha (Edt.), History of Bengal,Cal-1967,"Agrarian Relation in Bengal"Binoy Chaudhury,p.288-294.,Pradip

Sinha:Nineteenth Century Bengl,(Cal-1965,pp.22-37

9. N.Kabiraj-A peasant Uprising on Bengal,New Delhi,1972,p.89

10. B.S.Das.Ibid, P. 160

11. Smith to Lewis, 6 May, 1774,

Midnapore District Record, Vol-III, Nos, 335-340

12. H.H.wilson, History of British India, 5th ed,IX.220-221. 
tribal and non-tribal sentimants "and the forces of "Hinduization" of the tribal chiefs and its repercussions "taking into account the mods and tendencies of these simple tribal folk." 13

Many scholars analysed these movements as their experience.To the Marxist historians, on the other hand , "the revolt ruthlessly exposed the evil inherent in the colonial system of exploitation.It brought into focus the basic feature of colonial exploytation :the superimposition of an alien rule therby subverthing the law of independent social development of the oppressed nation."Populated by the peasants tribal .They also analysed that the foreign government, to consolidate its position entered into an unholy combination with the native feudal elements and with their support intensified their exploytation of the tribal peasantry."The primitive accumulation of capital ,through the monopoly market perpetrated by merchant capitalism, under the guise of looting,economy of the frontier Bengal leading to the tribal movements, famine condition,reluctant demographic changes and depopulation of villages. ${ }^{14}$

As the Marxist writers another class of the economic historians consider these revolts as a combination of privileged peasantry and the zamindars who since the sixteenth century exorted the social surplus in the form of free labour,rent is produced in the shape of "abwabs" and accumulated wealth in unholy connection with the merchant money lenders only to spend in the in competitive unproductive socio-religious expenses. The introduction of the Brithish revenue settlements not only threatened their social status,ruined their social roots of power established for generations throw wide administrative connections with the imperial machinery but it also led to their total dissociation from the cultivation process which only could ensure their extortion a surplus profit of leadership through land rent." 15 These historian painted the social leadership of Zamindars and Sardar as parasitic greed for extending their sphere of influence stimulated by land hunger.To some of them ,British rule proved ruinous to the rural economy leding to the continuous frustration of capital formatin consequent to decline in the agrarian sector typified by famines and migrations towards urban centres while no appreciable growth could be noticed in the rural economy due to the revolt of these feudal elements despite the response of all the Company's government to restore law and order and undertaking works of public utility,Even then they could not avert the crisis the agrarian economy leading to pauperization of the peasantry in absence of any qualitative change in the production relation. ${ }^{16}$

\section{Concluding remarks:}

It is very difficult to conclude what was the basic features of these movements.Being confused by these diverse theories and analytical models the peasant study would aim at analyzing the established facts and assess the contribution of historical forces for the causation and developments of these of these peasantised tribal unrest expressed exposed through four phases already mentined.But it would be difficult to visualized a tribal versus nontribal conflict in the peasant resistance movements. ${ }^{17}$

But still the question remains, were the "Chuar" revolt of 1799 and the Khurda revolt of 1817 a conscious attempt of the disgruntled paiks to terminate the colonial rule in the Jungle - Mahals and Orissa ?Analyzing the events it would appear that there was a no unionism like the Pabna league of 1873.Like the Sepoy Mutiny of 1857,it was essentially a feudal reaction of some disgruntled anarchical elements in the society who had no idea of ushering in a new industrial phase in the economic history of Jungle Mahals and Orissa.The movements were neither democratic nor widely popular and this explains the easy suppression of the movements on the point of the British bayonets .But like all other peasant movements of the period,the suppression of the revolts ,terminated the feudal phase of the economy in South West Bengal Presidency and laid the foundation ,however, indirectly a capitalist phase in the region. The permanent settlement in 1793 and the "Mahalwari" settlement of 1837 may be described as the capitalist

13.J.C Jha,The kol Insurrection of Chotonagpur,Cal-1964,pp.4-5

14. Karl Marx, Capital, I, Moscow ed.1956, PP.714-15

15.Binoy Bhusan Chaudhury, The Transformation of the Tribal society in middle India.,Presidential Address,J.H.C.Bhubaneswar,1977,same auther Transformation of Tribal system integration and Assimilation,EPW.Vol-XII.Nos-33-34

16. Chittabrata Palit (edt.)Agrarian Bengal Under the Raj, p.67.

17. K.S.Sing, "Colonial Transformation of rural pProtest in Eastern India, 1757-1930,Presidential Address ,Section -III,IHC,Waltair , 1978 
device of a colonial ruling machinery to introduce the norms of capitalism and the British finance capital in the agrarian sector of the frontier Bengal and Orissa.This is a proposition which demands adequate studies. ${ }^{18}$

From above discussion it is evident that the colonial rule witnessed numerous uprisings and disturbances in SouthWest Bengal during the period from 1799 to 1857. The nature of these disturbances varied from elitist to popular grassroots or people's movement. The tribal movements in the nature of ethnic movements usually tended to be resistance movements aimed at opposing the subtle and, at times, secretive efforts on the part of the non-tribal's, both British as well as the native people to penetrate in the preserved ethnic domains of the life of the tribals. For instance, when the tribal people felt certain perceptible threat to the basic components of their ethnic identity such as rituals, values, social structures, life styles, dialects, and so on, they put up stiff resistance. Such types of tribal movements were dominant in the early phase of the establishment of British rule in India. A number of tribal movements also came up in the nature of agrarian movements to oppose their exploitation at the hands of both colonial and native exploiter. Yet, the common point of all the tribal movements lunched on agrarian issues remained the strong sentiments of the people against exploitative politics of the colonial rules and strong arm tactics of the unscrupulous elements like Zamindars, moneylenders, and so on, which not only tended to destroy their means of livelihood but also put unbearable financial burden on them. Despite having their own share of ethnic as well as agrarian problems, these movements took the predominantly political form, presumably due to the nationalist perspectives of their leaders who thought of getting their problems redressed through the mechanism of national movement.

In these contemporary periods the practice of Indian history writings are being changed more or less. The Indian historian tried to change their traditional concept of history writing. It is to be mentioned that this type of history writing we have taken from out side of India.It was Italy where new historiography often starts .Borrowing from Gramsci the concept of "subaltern" and drawing on the prevailing Western ideas about the historiography of mass culture, Subaltern Studies tried to provide new interpretations and methodologies for writing Indian working-class history. Subalternists maintained that colonialist, nationalist, and Marxist interpretations of Indian history had denied the role of the common people and their agency. To rectify this situation, Subaltern Studies announced that its new approach would restore history to the subordinated. In addition, the group theorized that the elite in India played a dominant part during the colonial period and not merely a hegemonic role. With the logic of this new interpretation, the Subalternists were able to show that subordinated people (i.e., subalterns) were autonomous historical persons who acted on their own because they were not led by any elite group. Subaltern historiography tried to develop new kind of history writing based on the European Marxist style. By emphasizing the role of subaltern group 'independent from elite', they tried to highlight the contribution made by subaltern group in various kinds of revolt. It also brought the importance of subaltern group that there were not mere spectator in any revolt. In fact, they were conscious actor. Subaltern knew what they were doing and why they were doing. However, subaltern historiography could not provide systematic study and considered to be part of sub-history/local history though it filling up gap within history writing by unfolded many pages of Indian history by ferreting out many local records.Historically speaking,after the advancement of subalterns concept in India we will try to re-evaluate the tribal rebellions again. It is fact that the tribal's of frontier Bengal who understood the true independence of their life struggles. 